Boise State University

ScholarWorks

Political Science Faculty Publications and

Presentations

Department of Political Science

4-1-2018

\title{
Deadly Triangles: The Implications of Regional Competition on Interactions in Asymmetric Dyads
}

Michael A. Allen

Boise State University

Sam R. Bell

Kansas State University

K. Chad Clay

University of Georgia 


\title{
Deadly Triangles: The Implications of Regional Competition on Interactions in Asymmetric Dyads
}

\author{
Michael Allen \\ Boise State University
}

\author{
and \\ K. Chad Clay \\ University of Georgia
}

Sam R. Bell

Kansas State University

\begin{abstract}
Why do minor powers ever resist the demands of major powers? While recent work has begun to provide answers to this question, we argue that research has missed a vital piece of bargaining dynamics in dyadic research: third party influence. Using spatial modeling techniques for the Militarized Interstate Dispute and International Crisis Behavior datasets, we improve upon previous models of asymmetric conflict by showing that the presence of a neighboring rival of a minor power, and the relationship that rival has with a major power, conditions the likelihood that weak actors choose to fight the strong. The recent examples of Pakistan and Iraq, after the 9/11 terrorist attacks in the United States, serve as ideal types in which minor powers are respectively less and more likely to resist the demands of major powers. We find quantitative support that regional rivalry can act as both constrainers and enablers for minor powers when bargaining with major powers.
\end{abstract}

\section{Introduction}

What role does a state's regional security environment play in the decision of minor powers to resist the demands of major powers? A large percentage of interactions on the global stage, either in contest or in cooperation, exist between the strongest and weakest states in the system (Allen and Fordham 2011, Arreguín-Toft 2005). Many of these weak states simultaneously have to consider their relations with rivals and neighboring states when considering their relations with much more powerful states. The vast majority of these major-minor power interactions occur in a state of normalcy where the biases toward the powerful allow the strongest states to pursue and achieve their goals while the weakest states persist through the whims of the strong. This relationship is ideal for powerful states as the outcome of a war is obvious (the powerful will win) and the two states ought to make a settlement that both states prefer to actually going to war (Fearon 1995). While much of the empirical literature supports the contention that states at parity are more likely to engage in conflict with each other, there are times when minor powers resist the demands of the strong (Allen and Fordham 2011). We posit that the regional security environment of a weak state conditions its interactions with more powerful states.

We contend that these regional dynamics can work in two possible ways. First, it is possible that minor powers are emboldened towards distant major powers when facing a threatening neighboring rival. These more aggressive actions are the result of needing to signal strength and avoid the appearance of weakness to the more proximate threat of a neighboring rival. The interactions between the U.S. and Iraq in the buildup to the 2003 Iraq War exemplify this pattern as the Iraqi rivalry with Iran conditioned Saddam Hussein's behavior in the build up to the war. Second, the alternative is for a minor power to be further constrained than normal and be more willing to make concessions to a major power when faced with a demand. Pakistan's relationship with the United States post-2001 exemplifies this pattern as its rivalry with India contextualizes its behavior; any material loss or gain in Pakistan's decisions with the United States will alter its relative power with India. ${ }^{1}$

\footnotetext{
${ }^{1}$ We focus here on the power relations between the minor power in the dyad and its neighbors and rivals. However, we acknowledge that there are other factors that matter in these relationships, including other characteristics of the relations between the minor power and its neighbors.
} 
This is an author-produced, peer-reviewed version of this article. The final, definitive version of this document can be found online at Foreign Policy Analysis, published by Oxford Journals. Copyright restrictions may apply. doi: 10.1093/fpa/orw026

We employ the Militarized Interstate Dispute (MID) and Interstate Crisis Behavior (ICB) data as a testing ground for demands and escalation between major-minor power dyads from 1817-2000. We generate spatially weighted variables that account for military balance between a minor power, and its neighboring rivals, and find that these have an effect on the probability of whether or not a state resists the demand from a major power. Our findings indicate that whether the constraint or emboldening model holds depends on the relationship between the major power making the demand and the rival within the minor power's neighborhood.

\section{A Tale of Two Countries}

The extant research on minor-major power relationships is scant relative to the world politics scholarship that focuses on the interactions between major powers (Allen and Fordham 2011, Arreguin-Toft 2001, Paul 1994, Record 2007). Previous scholarship justified this focus under the assumption that the interactions between the strongest states in the international system have defined the characteristics of the system and the options available to other states. However, interactions within minor-minor and major-minor dyads are abundant (Arreguin-Toft 2005). The primary research we are interested in deals with demands and escalation between major-minor pairs in the international system.

While there are several studies that look at conflict within asymmetric (in power) interactions, such as those that pit states versus rebels (e.g. Mack 1975, Sullivan 2007, Arreguin-Toft 2001, Record 2007), states versus anti-colonization and de-colonization forces in extra-state wars (e.g. Goldsmith and He 2008, Santiago 2009), or terrorist groups (e.g. Crenshaw 1981, Pape 2003), the literature on the relative asymmetry between states is limited. This is partly a function of much of the inter-state conflict literature in international relations positing that war should be a function of power parity (Lemke and Reed 1996, Organski and Kugler 1980) or power disparity, where the powerful can do what they want and bargains short of war ought to be the obvious alternative (Fearon 1995, Waltz 1979). However, history has not confined the interactions between the powerful and the weak to demand and submission.

Paul (1994) examines cases in which minor powers initiate wars with major powers. In his comparative case analysis, Paul identifies four factors that explain minor power initiation, the strategic factor in relation to the tactics either side can adopt, the offensive weapons held by the minor power, alliance support, and the domestic structure of the minor power. Chan (2010) extends Paul's original analysis and provides additional insight to the puzzle. Chan posits that in cases of alliances and mutual alignments, it may be reasonable for a minor power to expect that a major power will intervene on its behalf during a dispute between the minor power and a state of an opposing international alignment. This emboldens the minor power to take on a stronger state. Record (2007), examining asymmetric wars between states and non-states actors, articulates the importance of including third party influence into elevating the weaker actors onto an advantageous playing field with the strong.

One attempt to examine asymmetric dyad escalation is by Allen and Fordham (2011); this study frames the manner in which we pursue our agenda. Their empirical investigation into why minor powers resist the demands of major powers covers a series of hypotheses, many of which Allen and Fordham extract from the aforementioned works. Primarily, the authors look at which unitary rational actor assumptions allow for conflict between states as well as some subnational decision making processes that may contribute to the behavior of weak actors in regards to major powers. In testing their argument on MID and ICB datasets, they find that the most consistent predictors of minor power resistance were if the demand concerned the minor power's regime, if it concerned the minor power's territory, if the major power used force to accompany the demand (ICB only) and if the major and minor powers were contiguous. However, these results do not exist in a vacuum and are contingent upon the choices by the major power to make a demand in the first place. Generally, the major power capabilities, contiguity of the major power to the minor power, the number of veto players in the minor power's territory, and the major power's polity score were influential in determining whether the major power made a demand of a minor power.

Within this framework, we model the interaction between a major power and a minor power as a two-stage interaction where the major power makes a demand attempting to alter the status quo between the states, and the state receiving the demand can either accept or reject (Fearon 1995; Fearon 1997). We assume the major power is a rational actor that has a range of options it can pursue in achieving what it wants in international relations. In attempting to better its position, it can make demands of other states to yield territory, change their policies or change their institutions. The decision to make a demand is contingent upon the major power believing that such a demand will be successful 
This is an author-produced, peer-reviewed version of this article. The final, definitive version of this document can be found online at Foreign Policy Analysis, published by Oxford Journals. Copyright restrictions may apply. doi: 10.1093/fpa/orw026

and it takes into consideration its past successes as well as global and regional considerations. Naturally, the major power is not perfect at predicting its own success and will face failure in some of its demands, even from the weakest states in the international system.

\section{Iraq, Pakistan, and Rivalry}

Both the buildup to the Iraq War in 2003 as well as the relations between the U.S., Pakistan, and India after the September $11^{\text {th }}$, 2001 terrorist attacks against the United States serve as illustrations of how neighboring rivalry can affect the interactions between major and minor powers. In the buildup to the Iraq War, the U.S. consistently demanded that Iraq adhere to the UN resolutions that required Iraq to abandon its Weapons of Mass Destruction (WMDs) programs. While post-war analysis provided ample evidence that Iraq had disarmed by 2003, Iraq refused to allow UN weapons inspectors to have unfettered access as demanded by the United States. Justice Department interrogations of Saddam Hussein report that his obfuscation and lack of cooperation with the UN was the result of concerns about Iranian threats and the need to appear powerful regionally (Department of Justice 2009b).

Iran and Iraq have maintained a rivalry for much of their shared history. This contestation between the two countries was further entrenched by policies during the Cold War period that US foreign policy formalized as "Dual Containment" in the 1990s (James 2000). The leaders of the countries internalized this view as, during his interrogation, Saddam Hussein stated that Iraq was the only check on Iran in the region, stating, "If Iran rose up against [neighboring Arab countries], Iraq would be the first to confront Iran's aggressiveness. The others were too fearful of Iran, and Iraq was the only one who stood up to them" (Department of Justice 2009a, 2). Hussein posits this fear of Iran's rise as to why he refused to capitulate to the United States:

Even though Hussein claimed Iraq did not have WMD, the threat from Iran was the major factor as to why he did not allow the return of the UN inspectors. Hussein stated he was more concerned about Iran discovering Iraq's weaknesses and vulnerabilities than the repercussion of the United States for his refusal to allow UN inspectors back into Iraq. In his opinion, the UN inspectors would have directly identified to the Iranians where to inflict maximum damage to Iraq...Hussein stated Iraq could have absorbed another United States strike for he viewed this as less of a threat than exposing themselves to Iran. (Department of Justice 2009b, 2).

Counter to this process, it is also possible that having regional adversaries can constrain a leader facing the choice of whether or not to acquiesce to the demands of a major power. Although not a militarized interstate dispute, the acquiescence of Pakistan to U.S. demands in the aftermath of 9/11 illustrates this constraining effect. Preceding the 9/11 attacks, and particularly in the aftermath of Pakistan's nuclear weapon testing, the relationship between these two countries was volatile. While there are many explanations for why Pakistan gave into U.S. demands and began cooperating in the war on terror, it is impossible to ignore the regional power dynamics involved. ${ }^{2}$ With a powerful regional rival like India next door, it becomes even more challenging for Pakistan not to cooperate with the United States. An interview with former President of Pakistan, Pervez Musharraf, in the Economic Times, a daily newspaper in India, reflects these concerns (Economic Times 2009). In this interview, responding to the prospects of the U.S. operating out of India instead of Pakistan, Musharraf elaborates, "If the [United States] come from India and we are not with them and what happens. Pakistan then has to oppose the might of US and India together" (Economic Times 2009). In this instance, acquiescence by a non-major power towards a major power resulted from the non-major power being constrained by its regional rivalry relations. ${ }^{3}$ The Pakistan-India-United States case offers a direct counter to the Iraq-Iran-United States relationship. While the United States had maintained sanctions on India up until the war on terror, it was now possible for the United States to forge a closer relationship with India in exclusion of Pakistan.

\footnotetext{
2 There is controversy over the extent to which Pakistan actually cooperates with the U.S. post-9/11. As a Council on Foreign Relations report from 2008 describes it, the leadership of Pakistan, starting with Musharaff and through Asif Ali Zardari, made commitments to cooperate in the war on terror and did pursue terrorist organizations with greater effort than previously. The major failures in cooperation have been the result of military defection from civilian control (Bruno and Bajoria 2008). What matters most for our purposes here is that the level of cooperation by Pakistan increased after 9/11, indicating some acquiescence to U.S. demands.

${ }^{3}$ The issue over which the U.S. makes demands across these two cases is different. It is possible that this difference has an effect on the willingness of each state to acquiesce. Although we cannot rule this out as a more important cause in this brief discussion of the two cases, we do attempt to control for the issue type in our empirical analysis and find that regional power dynamics continue to serve as a robust predictor of acquiescence.
} 
This is an author-produced, peer-reviewed version of this article. The final, definitive version of this document can be found online at Foreign Policy Analysis, published by Oxford Journals. Copyright restrictions may apply. doi: 10.1093/fpa/orw026

The Iraq/Iran and India/Pakistan scenario are not isolated cases; rivalry is a recurring phenomenon between states. The concept of rivalry helps to inform how we understand the effects that pairs of countries like these have on each other when dealing with third party actors. Much of the scholarship on rivalry focuses on identifying rivals, explaining how rivalries begin, and the effect of rivalry on conflict between the states (Bennett 1997, Goertz and Diehl 1993, Klein, Goertz, and Diehl 2006, Thompson 2001); this research has uncovered systematic effects of rivalries in global and regional contexts. Rival states are more likely to go to war (Diehl and Goertz 2001), outnumber non-rival wars, experience war during periods of parity (Geller 1993), erupt in bilateral wars (Goertz and Diehl 1992), and heighten the effect of other correlates of war (Colaresi and Thompson 2002). In addition, Akcinaroglu, Radziszewski, and Diehl (2014) show that states locked into multiple rivalries are more likely to be accommodating towards rivals that are less threatening to them when facing threats from another rival. This provides some evidence that the interaction between two rivals can condition interactions with other actors. We think that the interactions among rivals, and neighboring rivals in particular, is important to examine in the context of these asymmetric dyads.

The question then becomes: Which way does this relationship actually work in general? Is Saddam Hussein's thought process representative of the way leaders typically think about this strategic environment or are we more likely to observe that states are constrained when in a neighborhood with threatening states? In addition, are there any conditioning factors that help to shed light on when states will be constrained and when they will be emboldened?

This manuscript proceeds in four sections: The next section elaborates on our theoretical framework and resulting hypotheses in which we see minor powers interacting with major powers. The second section specifies our research design, methodology, and the data we use for testing our hypotheses. The third section discusses the results of our model estimations and the inferences we draw from them in regards to both our hypotheses and the existing literatures. Finally, we conclude the manuscript with the implications of the research.

\section{Deadly Triangles}

The rivalry literature produces a consistent narrative: the existence of rivalry fundamentally alters how a state relates to its rival as well as to other powers. The Iran-Iraq-U.S. dynamic suggests that a minor power locked into rivalry with another state might be encouraged to discount threats from other states for a few different reasons. First, the threat from a distant major power is historically less likely to break out into conflict than a threat from a proximate rival. Second, giving into a major power can shift the perceived balance of power unfavorably against the minor power in its relations with nearby rivals. Thus, even if the major power could overcome the commitment problem in international bargaining, it cannot offer guarantees against the minor power's rival pursuing its newfound advantage; fundamentally, this would be a third-party commitment problem. All of this increases the risks associated with acquiescing to the major powers demands and suggests that minor powers will be more likely to resist the demands of major powers when faced with a more proximate and credible threat.

The existence of nearby rival states enhances the importance of the threat and parity with that rival amplifies it further. Why parity? Naturally, not all rivals are equal. Rivalries at parity are much more conflictual (Geller 1993) and, thereby, increase the salience of interactions with the rival. In the case where rivals are much stronger or weaker than a minor power is, these third party concerns are less likely to matter. When there is disparity between the minor power and the rival, there is less uncertainty about who is likely to win and lose a war, and the interactions with the major power are much less likely to change those perceptions. However, under parity, and greater uncertainty about whether the minor power or the rival is likely to win a war (Reed 2003), the information revealed during interactions between the minor power and the more distant major power can have a more consequential effect on perceptions within the neighboring rivalry. If the minor power were much stronger than its rivals were, posturing would be unnecessary. If the minor power were much weaker than its neighboring rivals were, posturing and not ceding to the demands of a major power would do little to convince the rivals that the minor power is strong.

Regional dynamics seem to play a particularly important role here as well. Indeed, there is good reason to suspect that rival proximity increases that rival's salience. Given the well-established findings pointing to contiguity as a strong predictor of interstate conflict (Starr and Most 1976), having rivals located next door can increase the need to appear strong and make a state less likely to acquiesce when bargaining with major powers. As a result, minor powers that have neighboring rivals close to parity with them or have a number of neighboring rivals that are, on average, close to parity will be more likely to resist demands from a major power. 
This is an author-produced, peer-reviewed version of this article. The final, definitive version of this document can be found online at Foreign Policy Analysis, published by Oxford Journals. Copyright restrictions may apply. doi: 10.1093/fpa/orw026

\section{Hypothesis 1: A minor power is more likely to resist the demand of a major power if it has a neighboring rival at parity or if its average neighboring rival is at parity with it in terms of power. ${ }^{4}$}

However, rivalry dynamics may influence the relationship between a minor power and a major power external to the rivalry in another way. While the above logic suggests that parity with a neighboring rival emboldens a minor power in its interactions with a major power, an alternative logic suggests that parity with a rival constrains a minor power. It is important to note that this alternative logic still points to power parity with neighboring rivals, but instead suggests that parity with a rival is the point at which a minor power is least likely to resist the demands of a major power.

Recall that, under the emboldening hypothesis, rivalry is important for the interactions between the minor and major power because the minor power is concerned that acquiescence to the major power will signal weakness to its neighboring rival. When at parity with the rival, that weakness might be just enough to allow the rival to demand more in their interactions. Under the constraint hypothesis, the outside neighboring rivalry is important for interactions between the minor and major power because resisting the major power might require the use of resources that can be dedicated to interactions with the neighboring rival and give the major power an incentive to provide aid to the minor power's rival. At parity, this diversion of resources to a conflict with a major power and any extra support from the major power to the minor power's rival can be the difference between winning and losing a war with the proximate rival. As the minor power becomes stronger than its neighboring rivals, there are fewer constraints on resisting the demands of a major power, as it is less likely that the diversion of resources will change the regional balance of power in a consequential way. Similarly, when the minor power is increasingly weaker than its neighboring rival, it is unlikely that the diversion of resources to the major power or aid from the major power to the neighboring rival will change which state has the advantage in bargaining. In other words, the minor power is no longer constrained by the rivalry when at disparity. As the rivalry moves away from parity, it is less necessary for the minor power to consider the rivalry in its interactions with the major power.

When a minor power, facing a challenge from a major power, is also facing a local threat, the minor power cannot risk escalating the crisis with the major power. Any resources used in combating the major power will leave the minor power vulnerable to its rival. Like with Pakistan and India, it is also possible that the minor power will be fearful that the major power will support its rival and present an even greater threat than previously. The major power can use rivalry as an opportunity to exploit the minor power. This leads to an additional hypothesis about neighboring rivals:

Hypothesis 2: A minor power is more likely to resist the demand of a major power if it has a neighboring rival at parity or its average neighboring rival is at parity with it in terms of power. ${ }^{5}$

The above arguments produce a competing set of hypotheses. The first hypothesis suggests that having proximate rivals at parity can actually embolden a minor power in response to a challenge from a major power. The second hypothesis suggests that a minor power with neighboring rivals at parity will be constrained in its ability to resist the demands of a major power. The key variable for this set of hypotheses is the level of parity between the minor power its neighboring rivals. Given that parity is the point at which conflict is most likely between rivals, this is the point at which minor powers would be either emboldened or constrained.

While it is possible that just one of the above logics holds more generally in the population, there is also the possibility that both of the above stories might work under varying sets of conditions. More specifically, it is possible that the relationship between the major power and the neighboring rivals of the minor power can change the extent to which the minor power is emboldened or constrained. For example, consider a triadic relationship where the major power has a friendly relationship with a neighboring rival that the minor power is at parity with. In the circumstance where

\footnotetext{
${ }^{4}$ Scholars have long been interested in strategic interaction, tied up with the assumption that state leaders are rational actors who should be able to ascertain the benefits and costs of their actions (Schelling 1960). This expectation does not exempt major powers. Rivalry and neighborhood dynamics might also have an effect on the demands that major powers make that mirrors our expectation about minor power behavior. A savvy major power might avoid situations where its demands are going to be rejected. More specifically, if the above logic holds, when a minor power is facing neighborhood rivals that are a threat, major powers should avoid making demands. These major powers would prefer to avoid the costs of war and this environment produces a minor power with greater resolve. We account for this possibility in our empirical models by estimating a Heckman selection model where the first stage has a dependent variable to proxy demands.

${ }^{5}$ These rivalry and regional characteristics of minor powers might also have an effect on the demands that leaders make. If minor powers are more constrained in their actions when in an environment with neighboring rivals at parity, major powers might be more likely to make demands. As a result, we also control for possible selection problems in testing this hypothesis.
} 
This is an author-produced, peer-reviewed version of this article. The final, definitive version of this document can be found online at Foreign Policy Analysis, published by Oxford Journals. Copyright restrictions may apply. doi: 10.1093/fpa/orw026

the major power has a good relationship with the minor power's neighboring rival, this is likely to constrain the actions of the minor power, as the major power and neighboring rival can more credibly threaten to cooperate. In other words, the major power can credibly claim to be able to affect that the balance of capabilities between the minor power and its rivals. This is consistent with the Pakistan-India-U.S. case, where the U.S. had a reasonably good relationship with India. Indeed, this relationship was at least strong enough that Musharraf commented that he was concerned about cooperation between the U.S. and India if Pakistan did not cooperate with the U.S. This all implies the first part of a conditional hypothesis:

Hypothesis 3a: When there is a similar set of foreign policy preferences between a major power and a minor power's neighboring rivals, shifts toward parity with the neighboring rival decrease the probability that the minor power resists the demands of the major power.

When there is a dissimilar foreign policy outlook between the major power and the rival of the minor power, we should expect to see the emboldening hypothesis at work. Under this set of circumstances, the major power has less ability to threaten credibly to support the minor power's rival and, as a result, has less ability to affect the state of the relationship between the minor power and its neighboring rivals. As a result, the minor power is freer to use its interactions with the major power to signal strength to its rival. In addition, the poor relationship between the major power and the neighboring rival might give the minor power greater leverage with the major power as the major power might seek the assistance of the minor power in its interactions with the regional rival.

This is in line with the set of relations in the Iraq-Iran-U.S. set of interactions. With Iraq and Iran as neighboring rivals, and Iraq receiving a demand from the U.S., it was unlikely that the U.S. would actually cooperate with Iran and alter the balance between Iraq and Iran. In fact, the U.S. had earlier supported Iraq in its war with Iran. In this scenario, Saddam Hussein was concerned that full acquiescence to U.S. demands would signal weakness to the more proximate rival, Iran, and resisted the demands of the U.S.

Hypothesis 3b: When there is a dissimilar set of foreign policy preferences between a major power and a minor power's neighboring rivals, shifts toward parity with the neighboring rival increase the probability that the minor power resists the demands of the major power.

\section{Research Design}

In our research design, we want to account for and model the strategic choice of the minor power to resist a demand from a major power (Allen and Fordham 2011). One dataset allows us to consider both the actions of the major power and the actions of the minor power: the Correlates of War (COW) Militarized Interstate Dispute (MID) data (Ghosn et al 2004). We generate this dataset using EUGene (v3.204), and the observations are restricted to dyads between major and minor powers (Bennett and Stam 2000) where the minor power has neighboring rivals. ${ }^{6}$ The unit of analysis is the major-minor power dyad, and we analyzed the years 1817-2000. Following the lead of Allen and Fordham, we operationalize major powers using the Correlates of War identification of major powers. ${ }^{7}$

As a robustness check, we also test the hypotheses using the International Crisis Behavior (ICB) database (v9.0) (Brecher and Wilkenfield 2000). The unit of analysis using the ICB is the major-minor power crisis, and we analyze the period 1918-2001. Allen and Fordham coded minor power resistance in a way that more explicitly captures when a government opts to resist rather than the more general form of resistance captured by the MID data. Collectively, the combined analyses enable us to have greater confidence in our findings. In the remainder of this section, we describe our econometric models, the dependent and independent variables, and the series of control variables we include.

\footnotetext{
${ }^{6}$ The spatially weighted measures of military balance between the minor power and its rivals are missing for any cases that do not have neighboring rivals.

${ }^{7}$ We opt for this standard of classifying major powers as it is in line with previous research on examining major power-minor power demands (Allen and Fordham 2011). While we recognize that there is debate within the literature of whether the coding rules for major powers is consistent, we use the Correlates of War for its standardization of the literature we are building from, and it minimizes the external variance between the research projects.
} 
This is an author-produced, peer-reviewed version of this article. The final, definitive version of this document can be found online at Foreign Policy Analysis, published by Oxford Journals. Copyright restrictions may apply. doi: 10.1093/fpa/orw026

\section{$\underline{\text { Model }}$}

Because the existing literature suggests that major powers are strategic in selecting which minor powers to target, there is potential for selection problems (Allen and Fordham 2011). If major powers target minor powers based on the minor powers' strategic constraints, then we may never observe minor powers in a position to resist demands from major powers. As a result, we estimate a censored probit model when analyzing the MID data (Heckman 1979). This allows us to estimate simultaneously the effect of a minor power's relations with its neighboring rivals on both the major power's demand and the minor power's probability of resistance. ${ }^{8}$ We estimate a single equation logit model for analyzing the conflicts in the ICB data.

\section{Dependent Variables}

To control for major power demands, and potential selection effects, we use a dependent variable that accounts for when a major power is the originator of a MID and has revisionist aims (Allen and Fordham 2011). This variable is dichotomous. The minor power resistance dependent variable for the censored stage of the selection model is coded as "any militarized action on the part of the minor power" (1034). While imperfect, this captures the use of organized force by the minor power and is more meaningful as an action, due to it being more costly than just rhetoric.

The ICB data does not provide a measure of demands or resistance to demands. Allen and Fordham (2011) coded a variable for whether a minor power resists a demand. They first identify all ICB cases where a major power initiates a crisis with a minor power. From those cases, they use the ICB narratives to code whether that demand is accepted (1036).

\section{Measuring Neighboring Rival Parity and Disparity}

To create the weighted rivalry and spatially weighted measures, it is necessary to identify the presence of rivalry between two states and the balance of state capabilities between the minor powers and their rival neighbors. We identify rivals using the expanded Diehl and Goertz rivalry dataset produced by Klein et al. (2006). While there is an extant debate over the definition of rivalry, we use their definition as it offers a clear set of breakpoints for the end and beginning of rivalry based on MID interaction-ultimately the event that matters for our asymmetric dyads (Akcinaroglu et al. 2013; Lu and Thies 2013).

This allows us to identify rivals for the entire period under study. We produce the rival and spatially weighted variables using the COW's Composite Indicators of National Capabilities (CINC) index (Singer et al. 1972). From the CINC scores, we create two measures of capabilities to capture the level of disparity between the minor power and the rival. First, we construct a simple directed measure of relative capabilities as the share of dyadic capabilities the minor power possesses in reference to its rivals. We measured relative capabilities as follows:

$$
\text { Capability Balance }=\frac{\text { Minor Power }(\text { Capabilities })}{\text { Minor Power }(\text { Capabilities })+\text { Rival }(\text { Capabilities })}
$$

This measure ranges from 0 to 1 , with low values indicating weakness, middle values indicating parity, and high values indicating strength. From this measure, we construct the following disparity measure:

$$
\text { Disparity }=\mid 0.5-\text { Capability Balance } \mid
$$

When capability balance is equal to .5 (parity), this measure takes on the value 0 . Any shift away from parity will produce increases in the value of this measure, regardless of which state is increasing in capabilities. A value of .5 on the disparity measure indicates complete disparity whereas a 1 indicates that a state holds all of the capabilities in a dyad. We transform these two capability measures, together with the measure of rivalry, to create variables that capture power parity between a minor power and neighboring rivals.

\footnotetext{
${ }^{8}$ One limitation of using the MID data is that using the initiation of a militarized action as our operationalization left-censors cases where there is a non-militarized demand, the minor power acquiesces to the demand, and the demand never becomes militarized. For example, the MID models do not allow for a true test of the Pakistan case as the US-Pakistan negotiations do not become militarized and, functionally, this increases the bias against finding results for the acquiescence hypotheses.
} 
This is an author-produced, peer-reviewed version of this article. The final, definitive version of this document can be found online at Foreign Policy Analysis, published by Oxford Journals. Copyright restrictions may apply. doi: 10.1093/fpa/orw026

To measure the characteristics of neighboring rivals, we created spatially weighted variables based on regional attributes of states. In order to capture neighborhoods for the entire period under study (1817-2000), we used the direct contiguity measure found in EUGene (Bennett and Stam 2001, Stinnett et. al. 2002). Acknowledging that a neighborhood can be defined more broadly then those states with direct contiguity, and that there are island states with nearby neighbors, we defined states as neighbors if the contiguity measure showed that those states were either (1) directly contiguous or (2) separated by less than 24 miles of water. ${ }^{9}$

With the rivalry data, the contiguity data, and the two measures of capabilities discussed above, we generate four measures of neighboring rival power parity to test our hypotheses. We first create measures that capture when a minor power is close to parity with any neighboring rival and the average level of parity between the minor power and its neighboring rivals. We produce two different variables that capture parity with neighboring rivals. The variable disparity of rival closest to parity takes on the value of the level of disparity between a minor power and the rival with which it is closest to parity (a value of 0 on the disparity measure). The variable mean disparity of rival is the average of the disparity variable between a minor power and all of its neighboring rivals. We develop this measure using a connectivity matrix utilizing the rivalry and contiguity data. This matrix, $\boldsymbol{w}^{\text {neighrival }}$, is:

$$
w_{i j}^{\text {neighrival }}=\frac{\left(c_{i j} * r_{i j}\right)}{\sum_{j=1}^{n}\left(c_{i j} * r_{i j}\right)}
$$

where $c_{i j}$ equals 1 if countries $i$ and $j$ are either directly contiguous or separated by less than 24 miles of water and 0 if not, and $r_{i j}$ equals 1 if countries $i$ and $j$ were rivals in the year under consideration and 0 otherwise. We multiply this matrix by the vector of disparity data, yielding a measure of the average level of disparity among neighboring rivals.

We include these variables in both stages of the censored probit models and in the single equation ICB models. We create both the average disparity and closest to parity variables, as it is possible that having a single neighboring rival close to parity can be enough to embolden or constrain a state. Additionally, having neighborhood rivals in general (average) can condition minor power behavior. We check to see if either source of rivalry influences minor and major power behavior. The emboldening hypotheses suggest that the coefficients on these variables should be negative in the resistance equations. As a minor power moves toward disparity with its neighboring rivals, it will be more likely to resist demands. The constraint hypotheses suggest that the coefficient on these variables should be positive in the resistance equations. As a minor power moves toward disparity with its neighboring rivals, it will be less likely to resist demands.

We also generate a series of weighted transformations of the directional measure of the balance of military capabilities. From these measures, and their square terms, we conduct a robustness test of our hypotheses with a different operationalization of power parity. The first measure is the average rival balance between the minor power and its neighboring rivals. Similar to the measure of disparity, we also generate a measure of the military capability balance between the minor power and the rival it is closest to parity with. These military balance measures can take on values ranging from 0 to 1 , with low values indicating that the minor power is weaker than its neighboring rivals and high values indicating that the minor power is stronger than its neighboring rivals. ${ }^{10}$ We obtain these measures by multiplying the neighboring rivalry matrix by the CINC-based directional capabilities balance measure. We include these variables in both stages of the MID models and as independent variables in the single equation ICB models. With these variables and their respective square terms, we can identify whether the relationship is U-shaped as per the constraint hypothesis or an inverted U-shape as per the emboldening hypothesis. However, rather than assuming that the point of inflection is at .5 (parity), as in the disparity measures, this allows us to estimate and plot out where that inflection point is. The emboldening hypothesis predicts that the constituent term would be positive, with the square term negative in the reciprocation stage; the constraint hypothesis predicts the opposite.

Finally, we generate a series of measures to test hypothesis 3 , that there is a conditional relationship between minor power-neighboring rival parity and the state of the relationship between the major power and minor power's rival. We test this hypothesis with an interaction term between our two disparity measures and the s-score (Signorino and Ritter 1999) between the major power and the neighboring rivals. Consistent with how we construct the disparity measures, we generate the s-scores based on the two different conceptualizations of the minor power's rivals. One is based on

\footnotetext{
${ }^{9}$ We estimated models where this is set to 150 miles. The results remain substantively the same. These results can be found in the online appendix.

${ }^{10}$ We also examine the balance of power between the minor power and the sum of all its neighboring rivals' capabilities. The substantive results remain the same and are in the online appendix.
} 
This is an author-produced, peer-reviewed version of this article. The final, definitive version of this document can be found online at Foreign Policy Analysis, published by Oxford Journals. Copyright restrictions may apply. doi: 10.1093/fpa/orw026

the alliance portfolios between the major power and the minor power's rival that it is closest to parity with and the second is based on the mean s-score between the major power and all of the minor power's neighboring rivals. The sscores can theoretically vary between -1 and 1 , but in the full s-score dataset, the observed minimum is -.217 , and in the dataset used here, the minimum is -.187. We generate an interaction term between each disparity measure and its respective s-score. We interact this variable with the disparity measures and not the military balance measures because of the difficulty in interpreting an interaction with the quadratic specification. The expectation for the interaction terms is that at low values on the s-score, parity should lead to an increase in the probability of reciprocation to demands and at high values parity should lead to a decrease in the probability of reciprocation (MID) or resistance (ICB).

\section{Control Variables}

There is limited quantitative research on the causes of asymmetric conflict. Here we draw upon the series of control variables from Allen and Fordham (2011), but pare them down to those that attained statistical significance in their work. ${ }^{11}$ For the models employing the MID data, we include a set of control variables for each stage of the equation. We posit that the demand initiation stage is a function of the polity score of the major power, the relative power of the major power, whether or not the major and minor power are contiguous, the natural log of the minor power's population, dyadic peace duration, number of previous major power demands in the dyad, dyadic years since previous demand (control for autocorrelation between observations), and three temporal splines to account for time-related trends in the data. ${ }^{12}$ For the resistance stage, we include if the demand concerns the minor power's regime or territory, the polity score of the minor power, the polity score of the major power, and whether or not the two states are contiguous. The additional, unique predictors in the demand stage of the model allows the set of equations to meet the exclusion restriction thereby making the system of equations over-identified and able to produce consistent estimations (Sartori 2003).

In the demand stage, we use the Polity IV project's POLITY2 indicator (Marshall et. al. 2003), a 21-point variable that ranges from -10 (autocratic) to 10 (democratic). We expect that democratic regimes are less likely to make demands of targets. We draw the major power's capability from the COW project's National Military Capabilities data (v4.0) (Sarkees et. al. 2003, Sarkees and Wayman 2010), and we expect more capable major powers should associate with more demands as they have the capacity to threaten and carry out threats. Likewise, we draw the minor power's population from the Correlates of War data and expect a positive association with new demands. Contiguity comes from Stinnet et. al's (2002) work (v3.1); we expect contiguous states to have more major power-minor power demands due to their increased likelihood of conflict.

For the resistance stage, we draw the regime and territory demand variables from the MID dataset (Ghosn et.al. 2004). We expect both of these types of demands to encourage minor-power resistance as they are more difficult to reverse than demands about policy change or behavior. We draw the minor power's polity value from the same data set as the major power's polity value and we expect democratic states to be less likely to resist demands from major powers; democratic major powers should be less likely to have their demands rejected. Contiguous dyads (Stinnet et. al. 2002) should evoke fewer cases of minor power resistance as demands from contiguous major powers ought to carry more credibility (Allen and Fordham 2011).

In the single equation ICB models, in addition to the rivalry variable, we include variables representing the major power's polity score, if the demand concerns the minor power's independence, the polity of the minor power, if the two states are contiguous, the minor power's share of capabilities, and if the major power accompanies the demand with the use of force. The minor power's capabilities should make rejection more likely as it represents a stronger minor power. Finally, we also include whether the major power accompanies its demand with the use of force against the minor power. The variable represents a major power committed to carrying out a threat. However, the aforementioned research shows that the use of force makes resistance more likely. We hypothesize that this is a function of force accompany incredible demands and, in this case, we expect the use of force to represent demands

\footnotetext{
11 The research strategy of Allen and Fordham is to test as many competing theories about demands and resistance between major-minor partners. For several of these theories, they do not gain significant or consistent results; we only keep those that prove consistent. We conducted AIC and BIC tests using the full version of their model 4 compared to our pared down model and the AIC model suggests that there are minimal information gains by including the full model while the BIC test is favorable to the slimmer model.

12 While we include the splines in the estimations, we suppress the results in our report; the results are theoretically not as important as the reported variables. Our replication files contain the estimates for the suppressed coefficients.
} 
This is an author-produced, peer-reviewed version of this article. The final, definitive version of this document can be found online at Foreign Policy Analysis, published by Oxford Journals. Copyright restrictions may apply. doi: 10.1093/fpa/orw026

that are more likely to be resisted. In both stages of the MID models, as well as the ICB models, we include control variables for the CINC score for the minor power. This is to control for any independent effect that these have on the interactions between the major and minor power.

\section{Results}

\section{Militarized Interstate Dispute Results}

The four models in Table 1 substitute each operationalization of disparity between the minor power and its neighboring rivals. The first model in Table 1 includes the measure of the minor power's level of disparity with its rival closest to parity with it, the second model includes the level of disparity that the minor power has with its average rival, the third model includes the military balance between the minor power and its average neighboring rival and its square term, and the fourth model includes the military balance between the minor power and its neighboring rival it is closest to parity with and its square term. In the two models with the measures of disparity, the coefficients on the neighborhood disparity and average disparity measures are positive, and statistically significant. This indicates that shifts toward disparity lead to decreased probabilities of MID resistance. This is consistent with hypothesis 2 , that minor powers are likely to be constrained in their interactions with major powers when at parity with neighboring rivals. ${ }^{13}$

Table 1: Censored Probit Models- MID

\begin{tabular}{|c|c|c|c|c|}
\hline & Model 1 & Model 2 & Model 3 & Model 4 \\
\hline \multicolumn{5}{|l|}{ Reciprocation Stage } \\
\hline Disparity of Rival Closest to Parity & $\begin{array}{l}1.114^{* *} \\
(0.506)\end{array}$ & & & \\
\hline Mean Disparity of Rivals & & $\begin{array}{l}1.795^{* * *} \\
(0.684)\end{array}$ & & \\
\hline Mean Rival Balance & & & $\begin{array}{l}-2.765^{* * *} \\
(1.020)\end{array}$ & \\
\hline Mean Rival Balance ${ }^{2}$ & & & $\begin{array}{l}3.178^{* * *} \\
(1.208)\end{array}$ & \\
\hline Balance Closest to Parity & & & & $\begin{array}{l}-2.467 * * \\
(0.985)\end{array}$ \\
\hline Balance Closest to Parity ${ }^{2}$ & & & & $\begin{array}{l}2.768 * * * \\
(1.045)\end{array}$ \\
\hline Minor Power CINC & $\begin{array}{l}2.404 \\
(2.056)\end{array}$ & $\begin{array}{l}3.842 * \\
(2.316)\end{array}$ & $\begin{array}{l}1.261 \\
(2.156)\end{array}$ & $\begin{array}{l}1.770 \\
(2.127)\end{array}$ \\
\hline Demand Regime & $\begin{array}{l}0.743^{* * *} \\
(0.276)\end{array}$ & $\begin{array}{l}0.738^{* * *} \\
(0.282)\end{array}$ & $\begin{array}{l}0.642 * * \\
(0.267)\end{array}$ & $\begin{array}{l}0.691^{* *} \\
(0.270)\end{array}$ \\
\hline Demand Territory & $\begin{array}{l}0.657 * * * \\
(0.176)\end{array}$ & $\begin{array}{l}0.686^{* * *} \\
(0.179)\end{array}$ & $\begin{array}{l}0.633^{* * *} \\
(0.170)\end{array}$ & $\begin{array}{l}0.645^{* * *} \\
(0.172)\end{array}$ \\
\hline Minor Power Polity & $\begin{array}{l}-0.0277^{* * *} \\
(0.0101)\end{array}$ & $\begin{array}{l}-0.0306^{* * *} \\
(0.0102)\end{array}$ & $\begin{array}{l}-0.0310^{* * *} \\
(0.0103)\end{array}$ & $\begin{array}{l}-0.0280 * * * \\
(0.00982)\end{array}$ \\
\hline Major Power Polity & $\begin{array}{l}-0.0104 \\
(0.0121)\end{array}$ & $\begin{array}{l}-0.0102 \\
(0.0122)\end{array}$ & $\begin{array}{l}-0.0123 \\
(0.0117)\end{array}$ & $\begin{array}{l}-0.0111 \\
(0.0118)\end{array}$ \\
\hline Contiguous & $\begin{array}{l}-0.783^{* * *} \\
(0.209)\end{array}$ & $\begin{array}{l}-0.807 * * * \\
(0.208)\end{array}$ & $\begin{array}{l}-0.816^{* * *} \\
(0.196)\end{array}$ & $\begin{array}{l}-0.812^{* * *} \\
(0.200)\end{array}$ \\
\hline
\end{tabular}

13 The disparity measures are not statistically significant in the demand stage of the model. 
This is an author-produced, peer-reviewed version of this article. The final, definitive version of this document can be found online at Foreign Policy Analysis, published by Oxford Journals. Copyright restrictions may apply. doi: 10.1093/fpa/orw026

\begin{tabular}{|c|c|c|c|c|}
\hline Constant & $\begin{array}{l}0.960 * * \\
(0.457) \\
\end{array}$ & $\begin{array}{l}0.666 \\
(0.525) \\
\end{array}$ & $\begin{array}{l}1.792^{* * *} \\
(0.399)\end{array}$ & $\begin{array}{l}1.701^{* * *} \\
(0.409)\end{array}$ \\
\hline \multicolumn{5}{|l|}{ Demand Stage } \\
\hline Disparity of Rival Closest to Parity & $\begin{array}{l}-0.215 \\
(0.189)\end{array}$ & & & \\
\hline Mean Disparity of Rival & & $\begin{array}{l}0.153 \\
(0.213)\end{array}$ & & \\
\hline Mean Rival Military Balance & & & $\begin{array}{l}0.455 \\
(0.380)\end{array}$ & \\
\hline Mean Rival Military Balance ${ }^{\wedge}$ & & & $\begin{array}{l}-1.023^{* *} \\
(0.429)\end{array}$ & \\
\hline Balance Closest to Parity & & & & $\begin{array}{l}0.216 \\
(0.380)\end{array}$ \\
\hline Balance Closest to Parity^2 & & & & $\begin{array}{l}-0.613 \\
(0.415)\end{array}$ \\
\hline Minor Power CINC & $\begin{array}{l}2.501^{* * *} \\
(0.959)\end{array}$ & $\begin{array}{l}2.728 * * * \\
(0.959)\end{array}$ & $\begin{array}{l}2.877 * * * \\
(0.984)\end{array}$ & $\begin{array}{l}2.842 * * * \\
(0.976)\end{array}$ \\
\hline Major Power Polity & $\begin{array}{l}0.00685 * \\
(0.00401)\end{array}$ & $\begin{array}{l}0.00685 * \\
(0.00400)\end{array}$ & $\begin{array}{l}0.00711^{*} \\
(0.00403)\end{array}$ & $\begin{array}{l}0.00669 * \\
(0.00401)\end{array}$ \\
\hline Major Power CINC & $\begin{array}{l}1.630 * * * \\
(0.376)\end{array}$ & $\begin{array}{l}1.603^{* * *} \\
(0.376)\end{array}$ & $\begin{array}{l}1.650 * * * \\
(0.375)\end{array}$ & $\begin{array}{l}1.656^{* * *} \\
(0.375)\end{array}$ \\
\hline Contiguous & $\begin{array}{l}0.861^{* * *} \\
(0.0726)\end{array}$ & $\begin{array}{l}0.835^{* * *} \\
(0.0720)\end{array}$ & $\begin{array}{l}0.819 * * * \\
(0.0731)\end{array}$ & $\begin{array}{l}0.824 * * * \\
(0.0729)\end{array}$ \\
\hline Ln(Minor Population) & $\begin{array}{l}0.0521^{* *} \\
(0.0230)\end{array}$ & $\begin{array}{l}0.0534 * * \\
(0.0227)\end{array}$ & $\begin{array}{l}0.0746 * * * \\
(0.0240)\end{array}$ & $\begin{array}{l}0.0632^{* * *} \\
(0.0231)\end{array}$ \\
\hline Previous Demand Years & $\begin{array}{l}-0.0776^{* * *} \\
(0.0111)\end{array}$ & $\begin{array}{l}-0.0776^{* * *} \\
(0.0111)\end{array}$ & $\begin{array}{l}-0.0728^{* * *} \\
(0.0112)\end{array}$ & $\begin{array}{l}-0.0732 * * * \\
(0.0111)\end{array}$ \\
\hline Number of Previous Demands & $\begin{array}{l}0.0298^{* * *} \\
(0.00980)\end{array}$ & $\begin{array}{l}0.0315^{* * *} \\
(0.00977)\end{array}$ & $\begin{array}{l}0.0288 * * * \\
(0.00986)\end{array}$ & $\begin{array}{l}0.0309 * * * \\
(0.00987)\end{array}$ \\
\hline Constant & $\begin{array}{l}-2.565^{* * * *} \\
(0.224)\end{array}$ & $\begin{array}{l}-2.665^{* * *} \\
(0.224)\end{array}$ & $\begin{array}{l}-2.806^{* * *} \\
(0.225)\end{array}$ & $\begin{array}{l}-2.693^{* * *} \\
(0.222)\end{array}$ \\
\hline Observations & 21724 & 21724 & 21724 & 21724 \\
\hline Uncensored N & 287 & 287 & 287 & 287 \\
\hline$\rho$ & -0.652 & -0.647 & -0.701 & -0.688 \\
\hline$\chi^{2}$ & $56.58 * * *$ & $58.55^{* * *}$ & $62.92 * * *$ & $61.71^{* * *}$ \\
\hline
\end{tabular}

Standard Errors in Parenthesis, ${ }^{*} \mathrm{p}<.1,{ }^{* *} \mathrm{p}<0.05,{ }^{* * *} \mathrm{p}<0.01$.

In Models 3 and 4, we include military balance variables with their respective square terms. In both models, the coefficient on the constituent term is negative and statistically significant at the .01 level and the coefficient on the square term is positive and statistically significant at the .01 level. This is consistent with the measures of disparity in 
This is an author-produced, peer-reviewed version of this article. The final, definitive version of this document can be found online at Foreign Policy Analysis, published by Oxford Journals. Copyright restrictions may apply. doi: 10.1093/fpa/orw026

Models 1 and 2. Figure 1 graphs this relationship based on Model $4 .{ }^{14}$ The $x$-axis represents the distribution of capabilities and the y-axis represents the probability of reciprocation. This figure shows that as the relative capabilities of the minor power increase to parity in reference to its neighboring rival, the probability of MID reciprocation decreases. After parity, the probability of MID reciprocation begins to increase again.

Figure 1

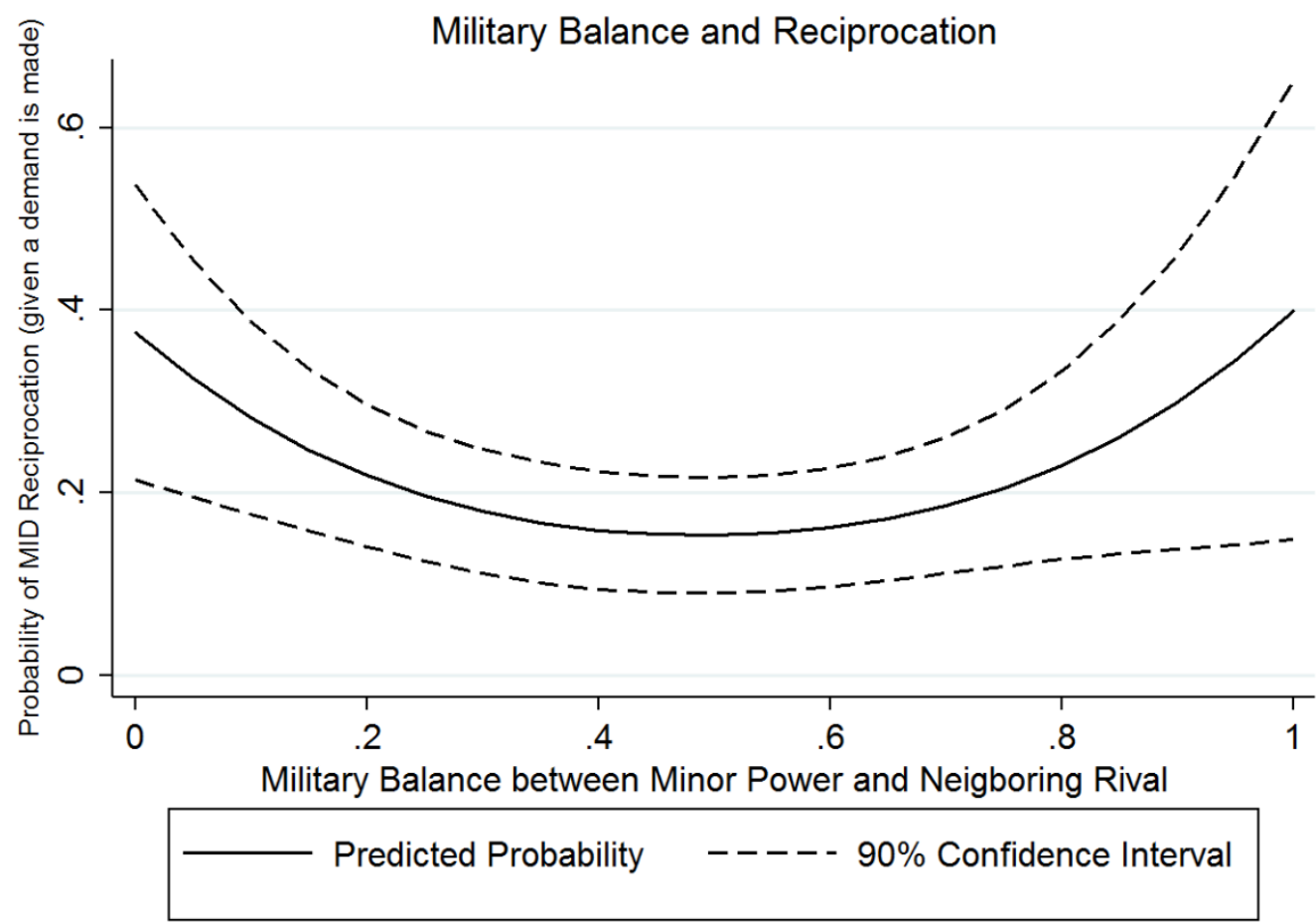

Our inclusion of the regional variables and paring down the models does not change the direction of the control variables or their impact from the original Allen and Fordham analysis. In the resistance stage, major power polity loses significance when we account for regional rivalry and power. Additionally, the parameter accounting for correlation between the two equations $(\rho)$ is significant in our estimations suggesting selection effects from the demand stage influence the resistance stage. The significant value of $\rho$ indicates that errors from the demand stage correlate with the errors from the resistance stage and the appropriateness of a selection model. ${ }^{15}$ The results from this first look at the data suggest that these rivalry and geographic dynamics serve to constrain the minor power, allowing the major power to exploit the minor power and gain concessions. This is consistent with the Pakistan-India case where the minor power is compelled to acquiesce to major powers because of concerns about conflict with neighboring rivals.

\footnotetext{
${ }^{14}$ We graphed this figure using the margins command in STATA 13.

${ }^{15}$ Although there seems to be non-random selection in the sample of states that are targeted with a MID in the first place, the estimates on the neighboring rival variables remain unchanged in models estimated without the selection model.
} 
This is an author-produced, peer-reviewed version of this article. The final, definitive version of this document can be found online at Foreign

Policy Analysis, published by Oxford Journals. Copyright restrictions may apply. doi: 10.1093/fpa/orw026

Table 2: Censored Probit Models- MID w/ interaction terms

\begin{tabular}{|c|c|c|}
\hline & Model 5 & Model 6 \\
\hline \multicolumn{3}{|l|}{ Reciprocation Stage } \\
\hline \multirow[t]{2}{*}{ Disparity of Rival Closest to Parity } & 0.879 & \\
\hline & $(2.965)$ & \\
\hline \multirow[t]{2}{*}{ S-score Major and Rival Closest to Parity } & -0.461 & \\
\hline & $(0.747)$ & \\
\hline \multirow[t]{2}{*}{ Closest to Parity*S-score } & -0.909 & \\
\hline & (3.950) & \\
\hline \multirow[t]{2}{*}{ Mean Disparity of Rival } & & $-5.086 *$ \\
\hline & & $(2.904)$ \\
\hline \multirow[t]{2}{*}{ Mean S-score Major and Mean Rival } & & $-2.689 * * *$ \\
\hline & & $(0.985)$ \\
\hline \multirow[t]{2}{*}{ Mean Rival Disparity*S-score } & & $8.194 * *$ \\
\hline & & $(3.447)$ \\
\hline \multirow[t]{2}{*}{ Minor Power CINC } & $6.879 * *$ & $5.067 * *$ \\
\hline & $(3.156)$ & $(2.484)$ \\
\hline \multirow[t]{2}{*}{ Demand Regime } & $1.004^{* * *}$ & $0.735 * * *$ \\
\hline & $(0.372)$ & $(0.278)$ \\
\hline \multirow[t]{2}{*}{ Demand Territory } & $0.783^{* * *}$ & $0.661 * * *$ \\
\hline & $(0.277)$ & $(0.180)$ \\
\hline \multirow[t]{2}{*}{ Minor Power Polity } & $-0.0326^{*}$ & $-0.0277 * * *$ \\
\hline & $(0.0169)$ & $(0.0102)$ \\
\hline \multirow[t]{2}{*}{ Major Power Polity } & -0.0195 & -0.0187 \\
\hline & $(0.0173)$ & $(0.0125)$ \\
\hline \multirow[t]{2}{*}{ Contiguous } & $-0.740 * *$ & $-0.820 * * *$ \\
\hline & $(0.293)$ & $(0.217)$ \\
\hline \multirow[t]{2}{*}{ Constant } & 0.940 & $2.890 * * *$ \\
\hline & $(0.795)$ & $(0.821)$ \\
\hline
\end{tabular}

\section{Demand Stage}

Disparity of Rival Closest to Parity $\quad-0.675^{* * *}$

(0.215)

S-score Major and Rival Closest to Parity $\quad 0.164$

(0.153)

Mean Disparity of Rival

0.135

Mean S-score Major and Mean Rival

Minor Power CINC

$(0.152)$

$3.268 * * *$

$2.263 * *$

Major Power Polity

(1.103) (0.976)

$0.00744 \quad 0.00988 * *$

(0.00456) (0.00412) 
This is an author-produced, peer-reviewed version of this article. The final, definitive version of this document can be found online at Foreign Policy Analysis, published by Oxford Journals. Copyright restrictions may apply. doi: 10.1093/fpa/orw026

\begin{tabular}{lll} 
Major Power CINC & $1.617^{* * *}$ & $1.841^{* * *}$ \\
& $(0.418)$ & $(0.384)$ \\
Contiguous & $0.609^{* * *}$ & $0.779^{* * *}$ \\
& $(0.0892)$ & $(0.0739)$ \\
Ln(Minor Population) & 0.0351 & $0.0559^{* *}$ \\
& $(0.0260)$ & $(0.0227)$ \\
Previous Demand Years & $-0.0659^{* * *}$ & $-0.0748^{* * *}$ \\
& $(0.0128)$ & $(0.0112)$ \\
Number of Previous Demands & $0.0648^{* * *}$ & $0.0310^{* * *}$ \\
& $(0.0124)$ & $(0.00974)$ \\
Constant & $-2.519^{* * *}$ & $-3.032^{* * *}$ \\
& $(0.280)$ & $(0.258)$ \\
\hline Observations & 20758 & 21719 \\
Uncensored N & 190 & 285 \\
$\rho$ & -0.533 & -0.670 \\
$\chi^{2}$ & $31.59^{* * *}$ & $64.82^{* * *}$ \\
\hline
\end{tabular}

Standard Errors in Parenthesis, ${ }^{*} \mathrm{p}<.1,{ }^{* *} \mathrm{p}<0.05,{ }^{* * *} \mathrm{p}<0.01$.

The models in Table 1 do not test for the possibility that the foreign policy similarity of the major power and the minor power's rivals conditions the relationship between the disparity measures and reciprocation. The results in Table 2 present a set of models that interact the two disparity measures with the s-score for the major power and the neighboring rival closest to parity with the minor power and the mean s-score between the major power and the neighboring rivals of the minor power. In Model 1 , the variables based on the neighboring rival closest to parity, the two constituent terms and the interaction term are not statistically significant. In Model 2, with the variables based on the mean of the neighboring rival, the constituent terms are both negative and statistically significant and the interaction term is positive and statistically significant. ${ }^{16}$

As Brambor, Clark and Golder (2006) explain, we cannot draw conclusions about the interactive effects without plotting out the marginal effect our disparity measure $(\mathrm{x})$ across different values of the s-score variable (z). In plotting out the effects from Model 5, the relationship between the level of parity between the minor power and its neighboring rival closest to parity is not statistically significant across any range of the s-score for the major power and the rival. However, the s-score for the major power in the dyad and the rivals of the minor power seems to condition the plotted effect of the level of parity between the minor power and its mean rival. In Figure 2, the x-axis represents varying levels of the s-score between the major power and the minor power's rivals. The y-axis is the marginal effect of a shift towards parity on the probability of MID reciprocation by the minor power. ${ }^{17}$ The graphed relationship shows that at low s-scores (poor relationship) between the major power and the average neighboring rival of the minor power, a shift towards parity between the minor power and its neighboring rivals increases the probability of reciprocation. This is representative of the Iraq-Iran-U.S. case where the U.S. had a poor relationship with Iran, and Iraq was willing to resist the U.S. because there was little threat that the U.S. would aid Iran and Iraq felt the need to signal strength to Iran. As the s-score increases, the relationship between parity and reciprocation becomes null and eventually negative and statistically significant, suggesting that once the relationship between the major power and the minor power's rivals is sufficiently strong, parity between the minor power and the rival constrains the minor power from reciprocating. In sum, the results in Model 5 do not provide support for hypothesis 3, but the results in Model 6 do

\footnotetext{
16 The results on the control variables remain substantively the same as the models estimated and discussed in Table 1.

17 This marginal effect is the result of a shift from the 75th percentile (0.37) to the 25th percentile (0.17) of our Mean Disparity of Rival measure.
} 
This is an author-produced, peer-reviewed version of this article. The final, definitive version of this document can be found online at Foreign Policy Analysis, published by Oxford Journals. Copyright restrictions may apply. doi: 10.1093/fpa/orw026

provide support for the possibility that the relationship between the major power and those regional actors conditions the effect of the minor power's regional context and that both the constraint and emboldening hypotheses are in force under different circumstances.

Figure 2

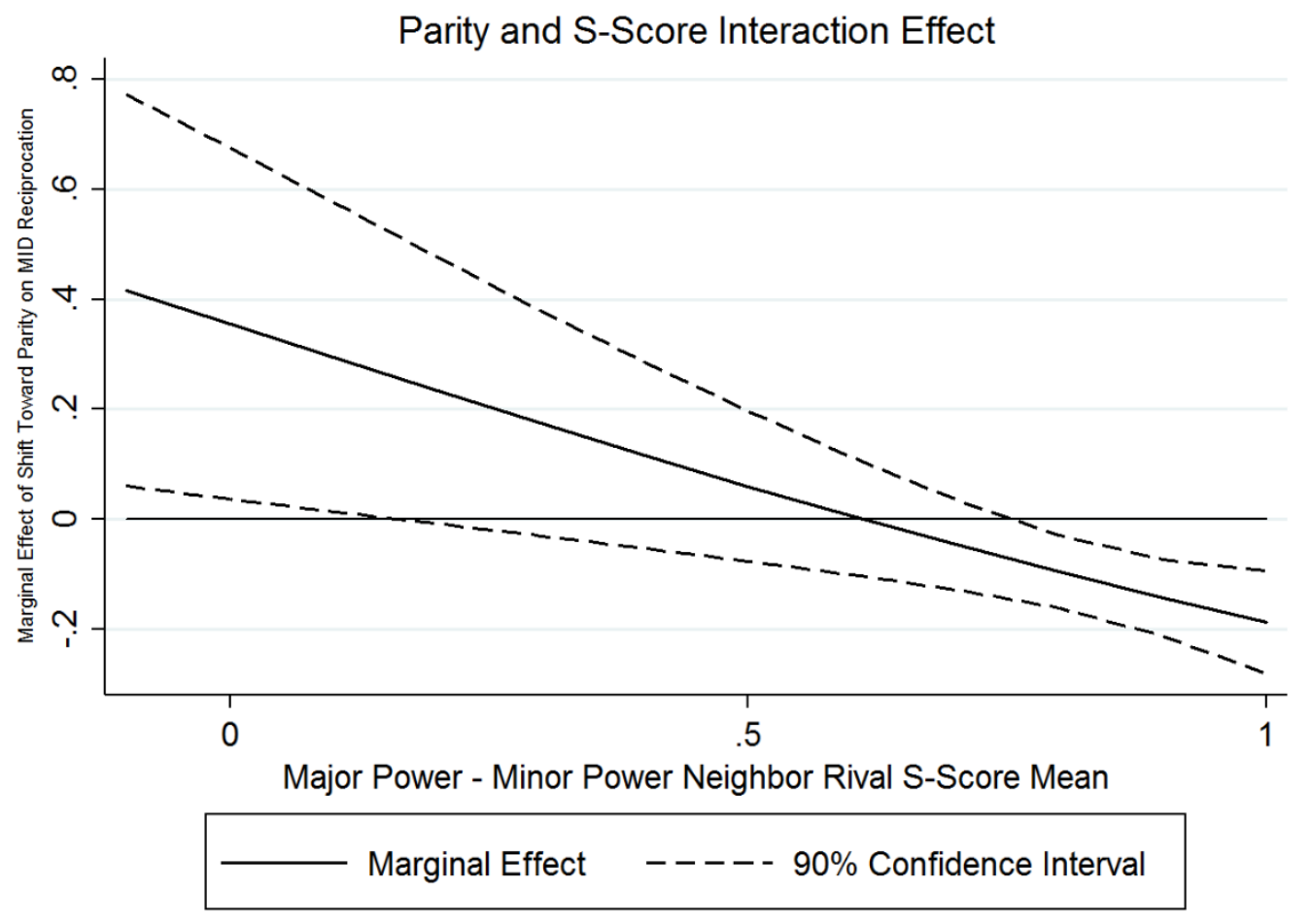

\section{$\underline{\text { ICB Results }}$}

The ICB models provide a more accurately coded measure of minor power resistance, but do not allow us to control for the demand stage. In addition, because the unit of analysis is the crisis and the temporal range is more restricted than the MID data, there are fewer cases in the sample. However, the results from these models provide some additional support for the conclusions drawn from the MID data.

The results from Models 7 through 10 in Table 3 largely mirror the results from Models 1 through 4 in Table 1. Both the disparity measures are positive and statistically significant. In Model 9, the constituent term on the mean rival military balance variable is not statistically significant, but the p-value is .11 . The square term in the model is statistically significant. In Model 10, where the military balance of the neighboring rival closest to parity with the minor power and its square term are both statistically significant and in the same direction as the MID models. Overall, the results here using the resistance dependent variable generated from the ICB data, largely confirm the findings from Table 1 using the MID data. 
This is an author-produced, peer-reviewed version of this article. The final, definitive version of this document can be found online at Foreign Policy Analysis, published by Oxford Journals. Copyright restrictions may apply. doi: 10.1093/fpa/orw026

Table 3: Logit Models - ICB Data

\begin{tabular}{|c|c|c|c|c|}
\hline & Model 7 & Model 8 & Model 9 & Model 10 \\
\hline Disparity of Rival Closest to Parity & $\begin{array}{l}5.271 * * \\
(2.392)\end{array}$ & & & \\
\hline Mean Disparity of Rivals & & $\begin{array}{l}6.654^{* *} \\
(2.801)\end{array}$ & & \\
\hline Mean Rival Balance & & & $\begin{array}{l}-7.864 \\
(4.934)\end{array}$ & \\
\hline Mean Rival Balance`2 & & & $\begin{array}{l}8.694 * \\
(4.758)\end{array}$ & \\
\hline Balance Closest to Parity & & & & $\begin{array}{l}-10.92 * \\
(5.582)\end{array}$ \\
\hline Balance Closest to Parity^2 & & & & $\begin{array}{l}13.25^{* *} \\
(5.559)\end{array}$ \\
\hline Minor Power CINC & $\begin{array}{l}1.194 \\
(15.52)\end{array}$ & $\begin{array}{l}1.312 \\
(15.09)\end{array}$ & $\begin{array}{l}-0.343 \\
(15.31)\end{array}$ & $\begin{array}{l}1.176 \\
(16.39)\end{array}$ \\
\hline Polity Minor Power & $\begin{array}{l}-0.0626 \\
(0.0477)\end{array}$ & $\begin{array}{l}-0.0855^{*} \\
(0.0503)\end{array}$ & $\begin{array}{l}-0.0631 \\
(0.0500)\end{array}$ & $\begin{array}{l}-0.0756 \\
(0.0490)\end{array}$ \\
\hline Demand Independence & $\begin{array}{l}1.196 \\
(1.231)\end{array}$ & $\begin{array}{l}1.391 \\
(1.197)\end{array}$ & $\begin{array}{l}1.499 \\
(1.293)\end{array}$ & $\begin{array}{l}1.777 \\
(1.328)\end{array}$ \\
\hline Polity Major Power & $\begin{array}{l}-0.206 * * * \\
(0.0643)\end{array}$ & $\begin{array}{l}-0.204^{* * *} \\
(0.0637)\end{array}$ & $\begin{array}{l}-0.213^{* * *} \\
(0.0641)\end{array}$ & $\begin{array}{l}-0.216^{* * *} \\
(0.0653)\end{array}$ \\
\hline Power Ratio: Minor & $\begin{array}{l}5.291 * * \\
(2.532)\end{array}$ & $\begin{array}{l}5.340 * * \\
(2.457)\end{array}$ & $\begin{array}{l}4.277^{*} \\
(2.417)\end{array}$ & $\begin{array}{l}5.508^{* *} \\
(2.718)\end{array}$ \\
\hline Demand with Force & $\begin{array}{l}1.587 * * * \\
(0.579)\end{array}$ & $\begin{array}{l}1.454^{* *} \\
(0.577)\end{array}$ & $\begin{array}{l}1.516^{* * *} \\
(0.565)\end{array}$ & $\begin{array}{l}1.781^{* * *} \\
(0.612)\end{array}$ \\
\hline Contiguous & $\begin{array}{l}-3.635^{* * *} \\
(1.194)\end{array}$ & $\begin{array}{l}-3.328^{* * *} \\
(1.156)\end{array}$ & $\begin{array}{l}-3.333^{* * *} \\
(1.182)\end{array}$ & $\begin{array}{l}-3.701^{* * *} \\
(1.211)\end{array}$ \\
\hline Constant & $\begin{array}{l}-0.406 \\
(0.748)\end{array}$ & $\begin{array}{l}-1.356 \\
(0.997)\end{array}$ & $\begin{array}{l}1.862 \\
(1.427)\end{array}$ & $\begin{array}{l}1.933 \\
(1.461)\end{array}$ \\
\hline Log Likelihood & -48.03 & -47.56 & -48.79 & -46.19 \\
\hline Observations & 94 & 94 & 94 & 94 \\
\hline
\end{tabular}

Standard Errors in Parenthesis, * $\mathrm{p}<.1,{ }^{* *} \mathrm{p}<0.05,{ }^{* * *} \mathrm{p}<0.01$. 
This is an author-produced, peer-reviewed version of this article. The final, definitive version of this document can be found online at Foreign Policy Analysis, published by Oxford Journals. Copyright restrictions may apply. doi: 10.1093/fpa/orw026

Table 4: Logit Models - ICB Data w/interaction

\begin{tabular}{|c|c|c|}
\hline & Model 11 & Model 12 \\
\hline Disparity of Rival Closest to Parity & $\begin{array}{l}-4.764 \\
(6.748)\end{array}$ & \\
\hline S-score Major and Rival Closest to Parity & $\begin{array}{l}-4.208 * \\
(2.172)\end{array}$ & \\
\hline Closest to Parity*S-score & $\begin{array}{l}16.17 \\
(10.90)\end{array}$ & \\
\hline Mean Disparity of Rival & & $\begin{array}{l}2.598 \\
(7.774)\end{array}$ \\
\hline Mean S-score Major and Mean Rival & & $\begin{array}{l}-2.922 \\
(3.025)\end{array}$ \\
\hline Mean Rival Disparity*S-score & & $\begin{array}{l}5.606 \\
(9.817)\end{array}$ \\
\hline Minor Power CINC & $\begin{array}{l}11.75 \\
(46.72)\end{array}$ & $\begin{array}{l}0.586 \\
(15.39)\end{array}$ \\
\hline Polity Minor Power & $\begin{array}{l}-0.0352 \\
(0.0612)\end{array}$ & $\begin{array}{l}-0.0816 \\
(0.0511)\end{array}$ \\
\hline Polity Major Power & $\begin{array}{l}-0.152^{* *} \\
(0.0708)\end{array}$ & $\begin{array}{l}-0.218 * * * \\
(0.0657)\end{array}$ \\
\hline Power Ratio: Minor & $\begin{array}{l}10.66 \\
(6.523)\end{array}$ & $\begin{array}{l}6.540 * * \\
(2.857)\end{array}$ \\
\hline Demand with Force & $\begin{array}{l}1.241^{*} \\
(0.653)\end{array}$ & $\begin{array}{l}1.335 * * \\
(0.585)\end{array}$ \\
\hline Contiguous & $\begin{array}{l}-2.357 * * \\
(1.171)\end{array}$ & $\begin{array}{l}-3.101^{* * *} \\
(1.182)\end{array}$ \\
\hline Demand Independence & & $\begin{array}{l}1.555 \\
(1.229)\end{array}$ \\
\hline Constant & $\begin{array}{l}1.329 \\
(1.364)\end{array}$ & $\begin{array}{l}0.501 \\
(2.253)\end{array}$ \\
\hline Log Likelihood & -35.15 & -46.96 \\
\hline Observations & 67 & 94 \\
\hline
\end{tabular}

Standard Errors in Parenthesis, * $\mathrm{p}<.1,{ }^{* *} \mathrm{p}<0.05$, *** $\mathrm{p}<0.01$.

Table 4 presents the ICB data models that include the interaction term between the disparity measures for the minor power and neighboring rival and the s-score for the major power and neighboring rivals of the minor power. Model 11 uses the measures based on the neighboring rival closest to parity and Model 12 uses the measures based on the average neighboring rival. Contrary to the models estimated in Table 2, using the MID data, the conditional relationship is present when utilizing the measures based on the neighboring rival closest to parity with the minor power (Model 11). Figure 3 illustrates this conditional relationship. ${ }^{18}$ At the low end of the s-scores, the marginal effect of a shift towards parity is positive, but short of conventional levels of statistical significance. However, as the s-score increases, and the major power has a sufficiently good relationship with the minor power's neighboring rival that it is at parity with, the probability of resistance in a crisis decreases and is statistically significant. This provides

\footnotetext{
${ }^{18}$ As with Figure 2, this marginal effect is the result of a shift from the 75 th percentile ( 0.31 in the ICB data set) to the 25 th percentile (0.17 in the ICB data set) of our Mean Disparity of Rival measure.
} 
This is an author-produced, peer-reviewed version of this article. The final, definitive version of this document can be found online at Foreign Policy Analysis, published by Oxford Journals. Copyright restrictions may apply. doi: 10.1093/fpa/orw026

evidence in support of hypothesis 3b, and some support for hypothesis 3a by demonstrating that the constraint of the regional context is no longer in place when the major power has a low s-score with the neighboring rival of the minor power.

Figure 3

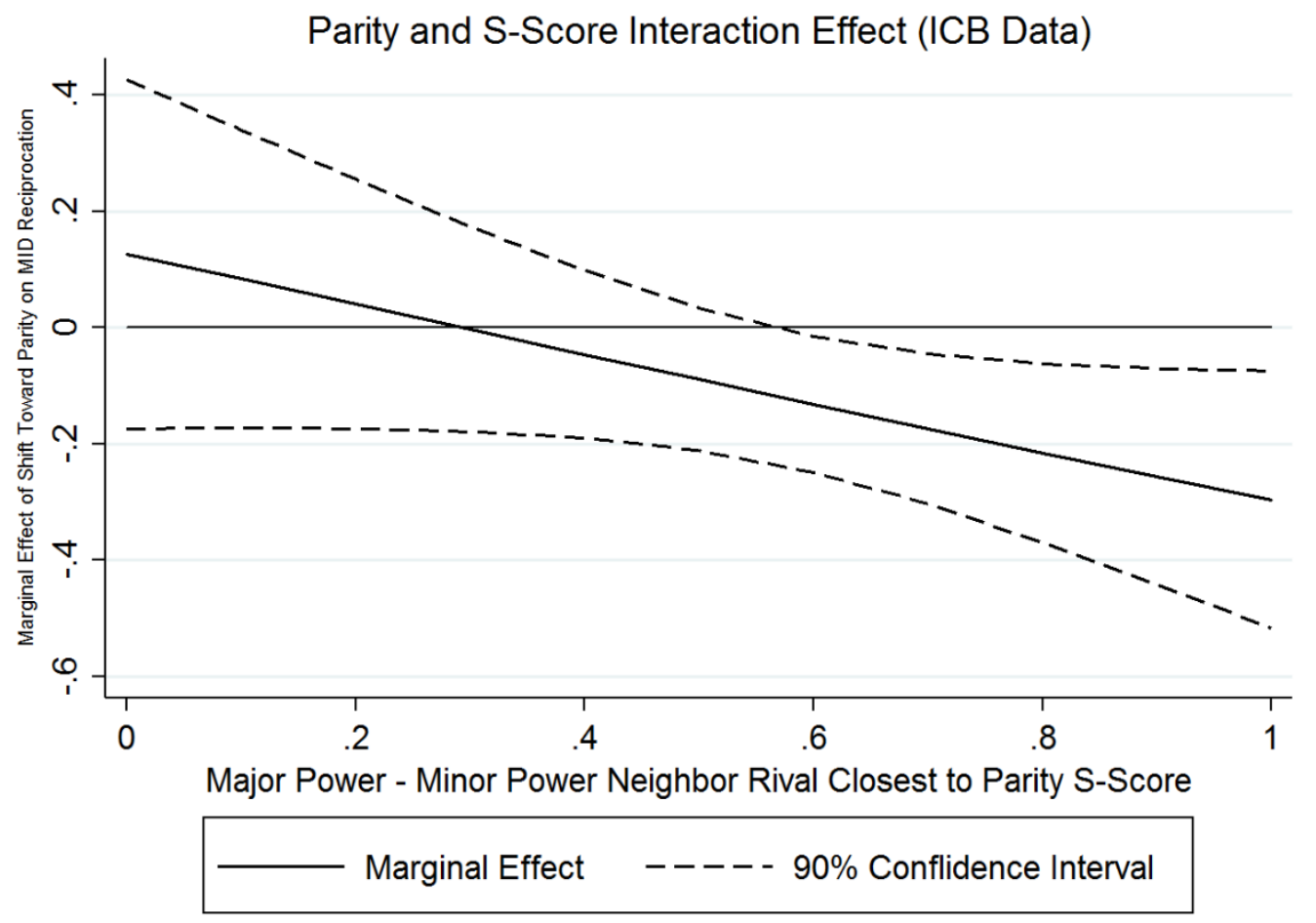

The control variables for the ICB data are consistent with our expectation and previous findings in both direction and significance. The main interpretation for these four models is that the existence of rivals for the minor power does matter for both the behavior of the major power and the minor power. Major powers are strategic and opportunistic, making demands when a minor power is constrained and expecting acquiescence. A minor power is most likely to reject those demands when it does not have a rival or is dominant in its region or rivalry.

\section{Conclusion}

We asked in our introduction whether the explanation that Saddam Hussein provided for his decision-making in the lead up to the 2003 war with the U.S. or the explanation that Pervez Musharraf provided for Pakistan's partial cooperation with the U.S. after 9/11 serve as general explanations for how third party dynamics influence asymmetric dyads. The evidence we offer here seems to suggest that both might be at play, but that it depends on the relationship between the major power and the minor power's regional adversaries. When a minor power is facing demands from a major power, has rivals that pose a threat to them, and those rivals have a good relationship with the major powers, the minor power is less likely to resist those demands. However, when the major power does not have a good relationship with the neighboring rival to the minor power, the minor power is able, and might be more likely, to resist the demands of the major power.

There remains room to look at the way in which minor powers select points of resistance versus points of acquiescence. We add one pivotal consideration by breaking away from traditional dyads and looking at regions of pressure for the minor states. While this is an important explanation, identifying additional regional factors that condition the interactions within asymmetric dyads could certainly be a fruitful endeavor. Future research should explore two tracts: First, research in international relations considers strategic interaction a high-level act of decision-making analysis, as it requires an understanding of two actors and how they anticipate the expected behavior of another party. Indeed, much of our empirical research has embraced this through dyadic quantitative research. However, limiting our 
This is an author-produced, peer-reviewed version of this article. The final, definitive version of this document can be found online at Foreign Policy Analysis, published by Oxford Journals. Copyright restrictions may apply. doi: 10.1093/fpa/orw026

research to two parties is ultimately self-defeating, as each actor is enmeshed within a web of strategic actors that gets geometrically bigger for every neighbor they have. We isolate rivals in this research because they are a primary security consideration for a minor power, but even non-rivals factor into the decision-making of a state.

Second, the influence of regional rivalry relationships does not just affect major-minor power bargaining over conflict, but leaves ripples across policy arenas from human rights and development to weapons of mass destruction and terrorism. These dependent variables of current international relations research are not isolated from regional considerations and regional competition likely affects the ability of states, international organizations, and non-state actors in their ability to expand such regimes to both willing and recalcitrant states. Future research should explore the triangular nature of regional rivals.

\section{References}

Akcinaroglu, Seden, Elizabeth Radziszewski, and Paul F. Diehl. (2013) "the Effects of Rivalry on Rivalry: Accommodation and the Management of Threats.” Foreign Policy Analysis 10(1):81-100

Allen, Michael and Benjamin Fordham. (2011) "from Melos to Baghdad: Explaining Resistance to Militarized Challenges from More Powerful States.” International Studies Quarterly 55(4):1025-1045.

Arreguin-toft, Ivan. (2001) How the Weak Win Wars: A theory of Asymmetric Conflict. International Security, 26(1):93--128.

Arreguin-toft, Ivan. (2005). How the Weak Win Wars: A Theory of Asymmetric Conflict. New York: Cambridge University Press.

Bennett, D. Scott. (1997) “Measuring Rivalry Termination, 1816--1992.” Journal of Conflict Resolution, 41(2):227$-254$.

Brecher, Michael, and Jonathan Wilkenfeld. (2000) A Study of Crisis. Ann Arbor: University of Michigan Press.

Colaresi, Michael \& Thompson, William R. (2002) "Strategic Rivalries, Protracted Conflict, and Crisis Escalation.” Journal of Peace Research, 39(3):263--287.

Chan, Steve. (2010) “Major-Power Intervention and War Initiation by the Weak.” International Politics, 47(2): 163185.

Crenshaw, Martha. (1981) "the Causes of Terrorism." Comparative Politics 13 (4):379-99.

Department of Justice, U.S. (2009a) "Casual Conversation, May 13, 2004” Federal Bureau of Investigation. $<$ http://www.Gwu.Edu/ Nsarchiv/NSAEBB/NSAEBB279/23.Pdf>. (Accessed March 21 2012).

Department of Justice, U.S. (2009a) “Casual Conversation, June 11, 2004” Federal Bureau of Investigation. $<$ http://www.gwu.edu/ nsarchiv/NSAEBB/NSAEBB279/24.pdf>. (Accessed March 21 2012).

Diehl, Paul F. \& Goertz, Gary. (2001) War and Peace In International Rivalry. Ann Arbor: University of Michigan Press.

Economic Times. (2009) "Pak Would Have Faced U.S. and India after 9/11: Musharraf” <http://Articles.economictimes.indiatimes.com/2011-09-09/news/30135686_1_dangerous-country-militaryruler-sovereignty>. (Accessed March 29 2012).

Fearon, James D. (1995) “Rationalist Explanations for War.” International Organization, 49(3):379-414.

Fearon, James D. (1997) “Signaling Foreign Policy Interests: Tying Hands versus Sinking Costs.” Journal of Conflict Resolution. 41(1): 68-90.

Geller, Daniel S. (1993) “Power Differentials and War In Rival Dyads.” International Studies Quarterly, 37(2):173193.

Goertz, Gary \& Diehl, Paul F. (1992) “The Empirical Importance of Enduring Rivalries.” International Interactions, 18(2):151-163.

Goertz, Gary \& Diehl, Paul F. (1993) "Enduring Rivalries: Theoretical Constructs and Empirical Patterns.” International Studies Quarterly, 37(2):147--171.

Ghosn, Faten, Glenn Palmer, and Stuart Bremer. (2004) "The MID3 Data Set, 1993-2001: Procedures, Coding Rules, and Description." Conflict Management and Peace Science, 21(2):133-154.

Goldsmith, Benjamin E. and He, Baogang. (2008) "Letting Go Without a Fight: Decolonization, Democracy and War, 1900-94.” Journal of Peace Research, 45(5):587--611.

Heckman, James J. (1979) “Sample Selection Bias as Specification Error.” Econometrica 47:153-161.

James, Carolyn C. (2000) "Iran and Iraq as Rational Crisis Actors: Dangers and Dynamics of Survivable Nuclear War.” The Journal of Strategic Studies, 23(1):52--73.

Klein, James P., Goertz, Gary, \& Diehl, Paul F. (2006) “The New Rivalry Dataset: Procedures and Patterns.” Journal of Peace Research, 43(3):331-348. 
This is an author-produced, peer-reviewed version of this article. The final, definitive version of this document can be found online at Foreign Policy Analysis, published by Oxford Journals. Copyright restrictions may apply. doi: 10.1093/fpa/orw026

Lemke, Douglas and William Reed. (1996) "Regime Types and Status Quo Evaluations: Power Transition Theory and the Democratic Peace.” International Interactions, 22(2):143-164.

Lu, Lingyu and Cameron G. Thies. (2013) "War, Rivalry, and State Building in the Middle East.” Political Research Quarterly. 66(2):239-253.

Mack, andrew. (1975) "Why Big Nations Lose Small Wars: The Politics of Asymmetric Conflict.” World Politics 27(2):175-200.

Marshall, Monty G., Jaggers, Keith, \& Gurr, Ted R. (2003) "Polity IV Project: Political Regime Characteristics and Transitions, 1800-2002." Polity IV.

Organski, A. F. K. \& Kugler, Jacek. (1980) The War Ledger. Chicago: University of Chicago Press.

Pape, Robert. A. (2003) “The Strategic Logic of Suicide Terrorism.” American Political Science Review, 97(3):343$-361$.

Paul, T. V. (1994) Asymmetric Conflicts: War Initiation by Weaker Powers. Cambridge, UK: Cambridge University Press.

Record, Jeffrey. (2007) Beating Goliath: Why Insurgencies Win. Washington D.C.: Potomac Books.

Reed, William. (2003) “Information, Power, and War.” American Political Science Review, 97(4):633-641.

Sarkees, Meridith R., Wayman, Frank W., \& Singer, J. David. (2003) "Inter-State, Intra-State, and Extra-State Wars: A Comprehensive Look at Their Distribution Over Time, 1816-1997.” International Studies Quarterly, 47(1):49--70.

Sarkees, Meridith R. \& Wayman, Frank. (2010) Resort to War, 1816-2007. Washington, D.C.: CQ Press.

Sartori, Anne E. (2003) “An Estimator for Some Binary-Outcome Selection Models Without Exclusion Restrictions.” Political Analysis. 11(4): 111-138.

Schelling, Thomas. (1960) "Strategy of Conflict”. Harvard University Press: Cambridge.

Signorino, Curtis S. and Jeffrey M. Ritter. (1999) "Tau-B or Not Tau-B: Measuring the Similarity of Foreign Policy Positions,” International Studies Quarterly 43(1):115-144.

Singer, J. David, Stuart Bremer, and John Stuckey. (1972) "Capability Distribution, Uncertainty, and Major Power War, 1820-1965." In Bruce Russett (Ed) Peace, War, and Numbers, Beverly Hills: Sage, 19-48.

Starr, Harvey, and Benjamin A. Most. (1976) "The Substance and Study of Borders in International Relations Research," International Studies Quarterly 20:581-620.

Stinnett, Douglas M., Jaroslav Tir, Philip Schafer, Paul F. Diehl, and Charles Gochman. (2002) "The Correlates of War Direct Contiguity Data, Version 3.” Conflict Management and Peace Science, 19(2):58-66.

Sullivan, Patricia L. (2007) “War Aims and War Outcomes.” Journal of Conflict Resolution, 51(3):496-524.

Thompson, William R. (2001) “Identifying Rivals and Rivalries in World Politics.” International Studies Quarterly, 45(4):557-586.

Waltz, Kenneth N. (1979) Theory of International Politics. Mcgraw Hill: New York. 